\title{
RETRACTION
}

\section{The relationship between lipid profile and erectile dysfunction}

M Nikoobakht, H Nasseh and M Pourkasmaee

International Journal of Impotence Research (2007) 19, 617; doi:10.1038/sj.ijir.3901620

International Journal of Impotence Research 2005; 17: 523-526. doi:10.1038/sj.ijir.3901350

The editor and the publisher wish to retract Nikoobakht et al. (http://www.nature.com/ijir/journal/ v17/n6/abs/3901350a.html) due to dual publication. The original form of this paper appeared in the Urology Journal (2005; 2: 40-44). 